\title{
Prioritizing Logistics Management Process by Using Balanced Scorecard (BSC) and Analytic Hierarchy Process (AHP) Technique
}

\author{
Alassane D., Yeo ${ }^{1 *}$, Eugenie M., Nyandwe ${ }^{2,}$ \& Valerie C., Assamoi ${ }^{3}$ \\ ${ }^{1}$ School of Economics and Trade, Hunan University, Changsha, China \\ ${ }^{2}$ School of Resources and Safety Engineering, Central South University, Changsha, China \\ ${ }^{3}$ School of Business and Social Sciences, Péléforo-Gbon-Coulibaly University, Korhogo, \\ Côte d'Ivoire
}

DOI - http://doi.org/10.37502/IJSMR.2022.5209

\begin{abstract}
The globalization, changing business environment, shorter delivery times, customer focus, and outsourcing have contributed to logistics' interest. Logistics operations have become increasingly efficient thanks to technological advances leading to the timely delivery of goods while reducing the cost involved. This paper developed an integrated BSC-AHP approach to the logistics management process by indicating the steps to implement and improve the logistics management process to meet customer requirements. A balanced scorecard was developed to identify actions to be undertaken to help the organization achieve its strategic goals. Analytic Hierarchy Process provides judgments about the relative importance of each stage of the logistics management process. Given the importance of logistics performance metrics, organizations need to be more responsive in assigning objectives and differentiate between the most urgent and the most important.
\end{abstract}

Keywords: logistics management process, balanced Scorecard, analytic hierarchy process, performance measurement.

\section{Introduction}

Logistics management is not a new concept. In the past, Logistics has served to supply soldiers in a world often marked by military and commercial wars. Team logistics was used primarily in the military application (Lummus et al., 2001; Pettit \& Anthony, 2005; Southern, 2011). Before 1950, the supply, maintenance, and transport of equipment and personnel could only be done using military facilities (Ballou, 2007). After the Second World War, companies recognized the importance of logistics and began to take advantage of logistics services. Moberg et al. (2004) suggest that the implementation of logistics management is the way to improve performance and then achieve company objectives.

Therefore, managing various logistical operations to achieve their objectives has posed a great challenge to the firm (Gunasekaran \& Kobu, 2007). Companies have recently become aware of the crucial and essential role that logistics management plays in competitive advantage. Logistics management can be considered as an extension of logistics or as a global approach 
to business integration. (Cooper et al., 1997). However, an emphasis has been placed on prioritizing the logistics management process's objectives to improve business performance. Murthy (2015), using the Balanced Scorecard (BSC), prioritized the three main functions for assessing the performance of $\mathrm{R} \& \mathrm{D}$, training, and education. He established three hierarchies to evaluate their potential contribution to organizational development goals, the probability of research success, and expected adoption rates, respectively. The prioritization of critical success factors and sub-factors helps practitioners understand their relative importance and develop an improvement plan (Chin et al., 2008). Sharma and Rajat (2007) integrated a balanced scorecard (BSC) analytical hierarchy process (AHP) approach for supply chain management (SCM) evaluation. This development BSC approach is based on an extensive literature review on SCM performance measures, supported by AHP analysis. The integrated BSC-AHP approach has been applied to different processes such as education (Ramasamy et al., 2016; Dobrovic and Sanja, 2008) government (Kohneh et al., 2013).

The proposed contribution is to identify the main stage in planning, implementing, and controlling procedures for the effective and efficient transportation and storage of goods and services to the point of consumption to meet customer requirements. In short, it is a question of determining which of the supply of raw materials, the manufacturer, distributors, wholesalers, and retailers constitutes the main stage in the distribution channel.

The rest of this paper is structured as follows. Section II provides a review of the recent literature relating to logistics management. Section III describes the methodology and approaches used in the study. Section IV presents the results and analyses. Section V concludes.

\section{Literature review}

Logistics is the process of strategic management of the purchase, movement, and storage of parts items and finished stock (as well as the related information flows) through the organization and its marketing channels (Lambert and Stock, 1993; Hausman, A. et al., 2006). The concept of logistics is one that has evolved the most over the years. Many other approaches have been associated with logistics, giving a broader meaning to its objectives, ranging from the simple mission of customer satisfaction to the issue of competitive advantage. Daugherty et al. (1996) confirm that internal and external integration is necessary to facilitate channelwide linkages and enhance channel efficiency. They focus their research on assessing the current implementation of the integrated logistics concept in US companies and supporting a relationship between integration and improved logistics performance. Cousins et al. (2006) systematically analyzed a total of 100 randomly selected peer-reviewed journal articles and obtained several key findings: the field is relatively "new"; several disciplines claim ownership of the field; there is no consensus on the definition of the term; the contextual focus is mainly on manufacturing industry. This study suggests that SCM should be framed as a Lakatosian research program as it has the greatest potential to help develop the body of SCM knowledge sustainably in the future.

However, supply chain management is a broader concept than logistics. Cooper et al. (1997) reveal that supply chain management is more than a new name for logistics. It is a 
comprehensive concept that combines several processes involving collaboration between companies to link suppliers, customers and other partners to drive efficiency and produce value for the end consumer. Logistics is essentially a planning orientation and framework that seeks to create a single plan for the flow of products and information throughout a company (Christopher, 1993). Supply chain management builds on this framework and seeks to link and coordinate the processes of other entities under development, namely suppliers and customers, as well as the organization. Supply chain management aims at the synergy between the different stakeholders, emphasizing cooperation, and trust (Rezaee, 2018). Therefore, sustainable and effective customer preference management can be achieved through better logistics and supply chain management.

\section{Methodology}

A survey was conducted among key business managers in Côte d'Ivoire to develop a way to use performance management to execute business strategies. Sales, marketing, corporate product management, research and development (R\&D), and supply chain operations are centralized and support all product lines. Logistics management flow procedures are used to guide logisticians in utilizing distribution channels to process raw materials to retailers before getting the customers. We hope to develop a framework that will enable those responsible for each of these functions to:

- Implement a plan for a performance measurement system

- Identify the leading logistics performance indicators

- Provide information for better decision-making and prioritize the logistics management process stages to satisfy the consumer better.

In an attempt to address these challenges, we propose a framework with the following steps:

- Determination of the objectives (BSC)

- Prioritization of the objectives (AHP)

- Determination of the link between BSC and logistics performance

- Analysis of alignment

\subsection{Balanced Scorecard (BSC)}

\subsubsection{Characteristics and evolution of the Balanced Scorecard}

Initially, the Balanced Scorecard model, developed by Kaplan and Norton in 1990 (Kaplan and Norton, 1998), is a method of formalizing company strategy and constructing prospective dashboards combining financial and non-financial indicators.

- The BSC approach proposes four axes of analysis covering financial results, customer satisfaction, internal processes, and organizational learning.

- This articulation allows a company to link its actions with its strategy and to assess the evolution of performance variables by adopting a global and balanced vision of its activities. 
- This idea of globality and balance, present in the BSC approach, highlights the notion of the cause-and-effect model, underlying the relationship between the four identified dimensions.

- Indeed, learning enables the improvement of internal processes, which generates customer satisfaction, which in the more or less long term enables the achievement of economic objectives and, therefore, shareholder satisfaction (Germain and Trébucq, 2004).

\subsubsection{Using of $\mathrm{BSC}$ in logistics management}

Using the Balanced Scorecard framework, each function has implemented actions and measures along four key dimensions, finance, customer, internal, and innovation and learning. Each function's objectives and actions were designed to support the logistics organization selected a set of measures to support business objectives (Kaplan and Norton, 1998). a guideline that allowed us to have up to 16 measurable objectives depending on the strategy to achieve. These are concrete and tangible actions that support the achievement of the objectives. Finally, the targets, which are the expectations in terms of the level of performance in relation to the strategic plan. For each measure, a goal or plan was developed to assess progress against the objective Performance indicators include the cash flow, return on investment and asset, the logistics cost, etc.

\subsection{The Analytic Hierarchy Process}

The analytic hierarchy process (AHP), developed by Thomas L. Saaty (1980) is designed to solve complex problems involving multiple criteria. The process requires the decision-maker to provide judgments about each criterion's relative importance and then to specify a preference for each decision alternative on each criterion. AHP generates all criteria weighting and alternative preference within each criterion by eliciting these values from the decision-maker through pairwise comparisons instead of directly utilizing numerical values.

The AHP procedure involves five essential steps:

- Building the hierarchy

- Establish Priority amongst Criteria Using Pairwise Comparison

- Estimate the relative weights

- Check the consistency

- Ranking. 


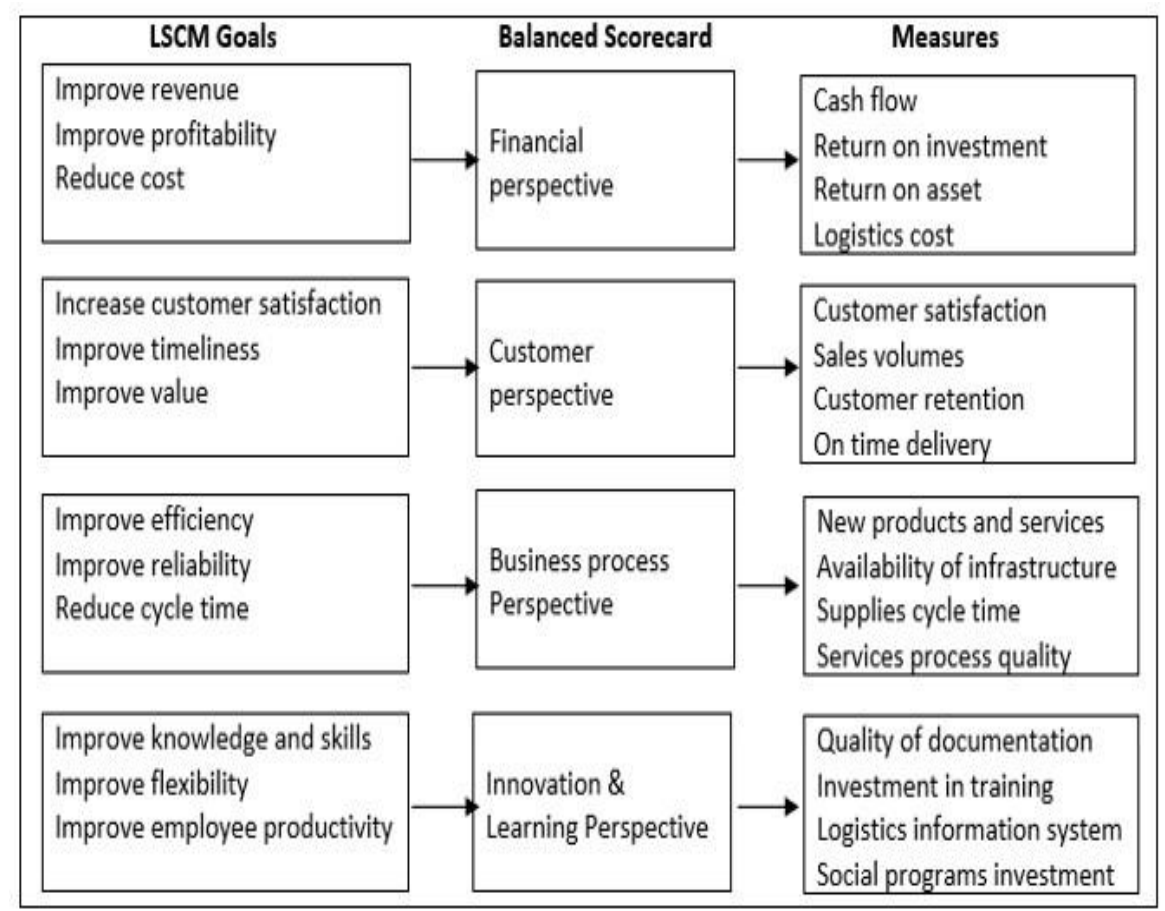

Fig. 1: LSCM goals with the BSC perspectives and their measures

\section{Step 1 Building the hierarchy}

In this step, the unstructured problem and its characters should be identified the relationships between criteria and alternatives, and the objectives and outcomes stated clearly. The following figure. 2 shows the hierarchy for the logistics management process problem. The first level of the hierarchy shows that the overall goal is to select the most efficient logistics management process stage. At the second level, we see that the four criteria (financial, customer, internal business, and innovation \&learning) will help achieve the overall goal. Finally, at the third level, we see that each decision alternative (raw material supplier, manufacturer, distributors, wholesalers, and retailers) can uniquely contribute to each criterion.

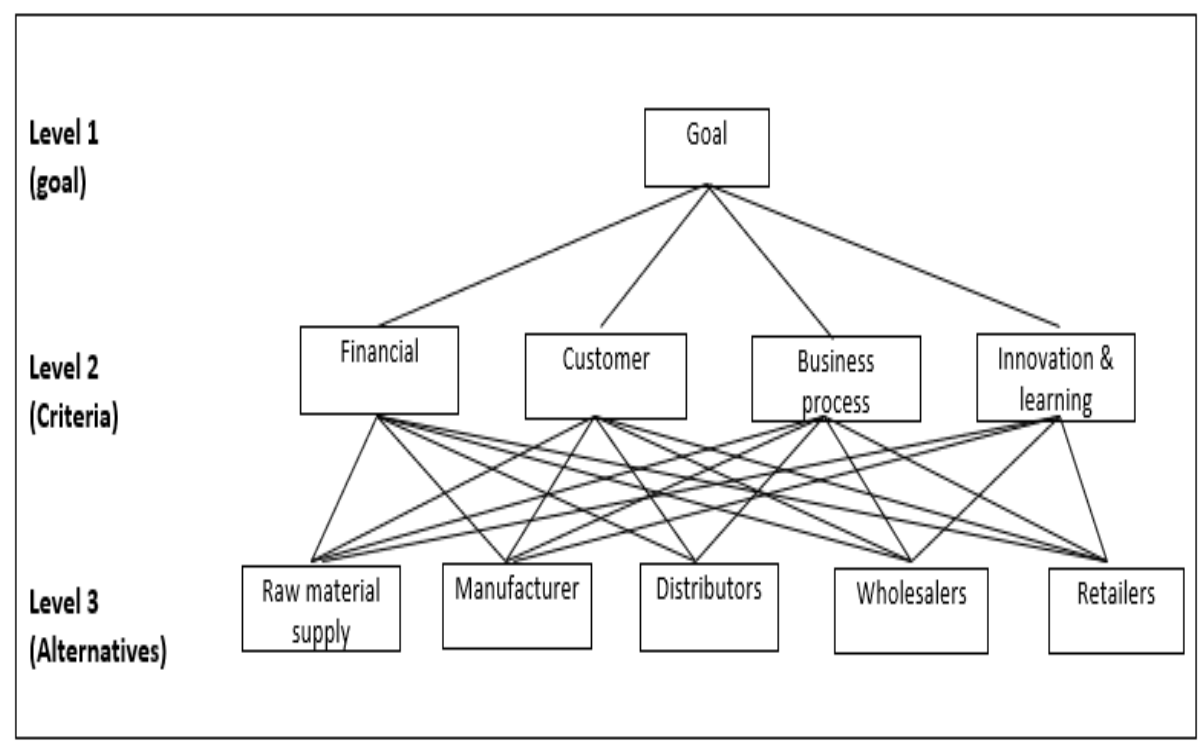

Fig. 2: Hierarchy structure of decision problem 


\section{Step 2: Establish Priority amongst Criteria Using Pairwise Comparison}

In this step, the AHP utilizes pairwise comparisons to establish priority measures for both the criteria and the decision alternatives. The sets of priorities that need to be determined in the selection problem are as follows:

- The priorities of the four criteria in terms of the overall goal

- The priorities of the five alternatives in terms of each criterion

The example scale for comparison is given by (Saaty and Vargas, 1991) in table 1 below.

Table 1: The fundamental scale of pairwise comparison for AHP

\begin{tabular}{|c|c|}
\hline scale & Degree of experience \\
\hline 1 & Equal importance \\
3 & Moderate importance \\
5 & Strong importance \\
7 & Very strong importance \\
9 & Extreme importance \\
$2,4,6,8$ & Values of inverse comparison \\
\hline
\end{tabular}

Reciprocals of above: in comparing elements $i$ and $j$; if $i$ is 3 compared to $j$, then $j$ is $1 / 3$ compared to $i$-rationales: force consistency, measured value available.

Results of the comparison (for each factor pairs) were described in terms of integer values from 1 (equal value) to 9 (extreme difference), where a higher number means the chosen factor is considered more important to a greater degree than other factors being compared.

\section{Decision matrix}

If the decision-making problem consists of $n$ criteria and $m$ alternatives, the decision matrix takes the form:

$$
f=\left[\begin{array}{cccc}
d_{11} & d_{12} & \cdots & d_{1 n} \\
d_{21} & d_{22} & \cdots & d_{2 n} \\
\vdots & \vdots & \ddots & \vdots \\
d_{m 1} & d_{m 2} & \cdots & d_{m n}
\end{array}\right]
$$

The elements $\left\{f_{i j}\right\}$ signify the rating of the $i t h$ alternative with respect to the ${ }^{j t h}$ criteria.

\section{Decision vector}

If the decision-making problem consists of $n$ criteria; the decision vector takes the form:

$$
w=\left\{\begin{array}{llll}
w_{1} & w_{2} & \cdots & w_{n}
\end{array}\right\}
$$

The elements $\left\{w_{i}\right\}$ signify the rating of the ith criteria preference.

\section{Pairwise comparison matrix}


To develop the five alternatives' priorities in terms of each criterion, we need to build a pairwise comparison rating matrix. The aim is to set their relative priorities for each of the elements at the next high level.

The pairwise comparison matrix based on the Saaty's 1-9 scale form:

$$
\left[\begin{array}{cccc}
a_{11} & a_{12} & \cdots & a_{1 n} \\
a_{21} & a_{22} & \cdots & a_{2 n} \\
\vdots & \vdots & \ddots & \vdots \\
a_{n 1} & a_{n 2} & \cdots & a_{n n}
\end{array}\right]=\left[\begin{array}{cccc}
w_{1} / w_{1} & w_{1} / w_{2} & \cdots & w_{1} / w_{n} \\
w_{2} / w_{1} & w_{2} / w_{2} & \cdots & w_{2} / w_{n} \\
\vdots & \vdots & \ddots & \vdots \\
w_{n} / w_{1} & w_{n} / w_{2} & \cdots & w_{n} / w_{n}
\end{array}\right]
$$

The element $\left\{a_{i j}\right\}$ must satisfy $a_{i j}=w_{i} / w_{j}=1 / a_{j i}$ and $a_{i i}=1$

\section{Step 3: Estimate the relative weights}

The eigenvalue method is used to calculate the relative weights of elements in each pairwise comparison matrix. The principal eigenvalue and the corresponding normalized right eigenvector of the comparison matrix give the relative importance of the various criteria being compared. The normalized eigenvector elements are termed weights with respect to the criteria and ratings with respect to the alternatives. The relative weights (W) of matrix A is obtained from the following equation: $\mathrm{AW}=\lambda_{\max } \mathrm{W} \quad \lambda_{\max }>=\mathrm{n}$

Where $\lambda_{\max }=$ the biggest eigenvalue of matrix $\mathrm{A}, \mathrm{I}=$ unit matrix, $\mathrm{A}=$ pair wise comparison.

\section{Step 4: Check the consistency}

Consistency is the key step in the AHP in establishing priorities by using the pairwise comparison procedure. If this consistency index fails to reach a required level, then answers to comparisons may be re-examined. The consistency index, $\mathrm{CI}$, is calculated as:

$$
\mathrm{CI}=\left(\lambda_{\max }-n\right) /(n-1)
$$

Where $\lambda_{\max }$ is the maximum eigenvalue of the judgment matrix, CI can be compared with a random matrix, RI. The ratio derived, CI/RI, is called the consistency ratio, CR. Saaty (1990) suggests that the value of CR should be less than 0.1 .

Table 2: Random consistency index.

\begin{tabular}{|l|l|l|l|l|l|l|l|l|l|l|}
\hline $\mathbf{N}$ & $\mathbf{1}$ & $\mathbf{2}$ & $\mathbf{3}$ & $\mathbf{4}$ & $\mathbf{5}$ & $\mathbf{6}$ & $\mathbf{7}$ & $\mathbf{8}$ & $\mathbf{9}$ & $\mathbf{1 0}$ \\
\hline RI & 0 & 0 & 0.58 & 0.9 & 1.12 & 1.24 & 1.32 & 1.41 & 1.45 & 1.49 \\
\hline
\end{tabular}

Source: Saaty (1990)

\section{Step 5: Ranking}

The output of the AHP is a prioritized ranking indicating the overall preference for each of the decision alternatives. First, the local ratings are multiplied by the criteria' weights and aggregated to get global ratings. Secondly, the AHP produces weight values for each alternative based on the judged importance of one alternative over another with respect to a common 
criterion. The calculation method of the total weight is described in table 3. The weighting of alternative $i$ with respect to criterion $j$ is weighting $s_{i j}$, the evaluation value is $w_{i j}$, the maximum evaluation value with respect to criterion $j$ is $w_{\max }, s_{\mathrm{ij}}=w_{\mathrm{ij}} / w_{\max } j$, and larger values indicate greater weighting of that item. In this case, the total weight $S_{i}$ of the alternative $i$ (where $i=1$, $2, \ldots, 5)$ with respect to the objective can be calculated as follows:

$$
S_{t}=s_{t 1} \cdot \alpha+s_{t 2} \cdot \beta+s_{t 3} \cdot \gamma+s_{t 4} \cdot \eta
$$

Table 3: Example of relative weights of each alternative for criterion

\begin{tabular}{|l|l|lr|l|l|}
\hline & $\begin{array}{l}\text { Criterion 1 (weight } \\
\alpha)\end{array}$ & $\begin{array}{l}\text { Criterion } \\
(\text { weight } \beta \text { ) }\end{array}$ & $\begin{array}{l}\text { Criterion } \\
(\text { weight } \gamma)\end{array}$ & 3 & $\begin{array}{l}\text { Criterion } \\
\text { (weight } \eta \text { ) }\end{array}$ \\
\hline Alternative 1 & $\mathrm{S}_{11}$ & $\mathrm{~S}_{12}$ & $\mathrm{~S}_{13}$ & $\mathrm{~S}_{14}$ \\
Alternative 2 & $\mathrm{S}_{21}$ & $\mathrm{~S}_{22}$ & $\mathrm{~S}_{23}$ & $\mathrm{~S}_{24}$ \\
Alternative 3 & $\mathrm{S}_{31}$ & $\mathrm{~S}_{32}$ & $\mathrm{~S}_{33}$ & $\mathrm{~S}_{34}$ \\
Alternative 4 & $\mathrm{S}_{41}$ & $\mathrm{~S}_{42}$ & $\mathrm{~S}_{43}$ & $\mathrm{~S}_{44}$ \\
Alternative 5 & $\mathrm{S}_{51}$ & $\mathrm{~S}_{52}$ & $\mathrm{~S}_{53}$ & $\mathrm{~S}_{54}$ \\
\hline
\end{tabular}

\section{Results and analysis}

\subsection{Criteria and sub-criteria results}

Table. 4 represents the local priorities of the criteria and their sub-criteria and the global priorities of the sub-criteria with respect to the goal. The global priorities are obtained by multiplying the local priorities of the sub-criteria by those of their criteria. The summary of the pairwise comparison matrix preferences for the four criteria is represented in table 4 . The results obtained allow us to convert the pairwise comparison information into the priorities for the four criteria. We can see that the financial perspective $(0.4123)$ has been identified as the highest priority or most important criterion in the logistics management process decision. Internal business (0.2994) and customer (0.2144) rank next in importance. Innovation \& learning $(0.0738)$ is the relatively least important criterion in terms of the overall objective.

Table 4: Performance measures (criteria) with respect to the goal

\begin{tabular}{|c|c|c|c|c|c|c|}
\hline Objective & $\mathbf{F}$ & $\mathrm{C}$ & IP & LG & $\mathbf{w}$ & CR \\
\hline $\mathbf{F}$ & 1 & 3 & 1 & 5 & 0.412386 & \multirow[t]{4}{*}{0.04} \\
\hline $\mathbf{C}$ & $1 / 3$ & 1 & 1 & 3 & 0.214385 & \\
\hline IP & 1 & 1 & 1 & 4 & 0.299405 & \\
\hline LG & $1 / 5$ & $1 / 3$ & $1 / 4$ & 1 & 0.073823 & \\
\hline
\end{tabular}

The sub-criteria determine how the criteria will be implemented. Based on the priority vector obtained for each criterion, the most important sub-criteria in the evaluation were Cash flow (0.184883), more important than the availability of infrastructure $(0.153764)$ followed by return on asset $(0.108686)$, sales volumes $(0.089115)$. However, the measurement of the degree 
of consistency among the pairwise judgments give the values of all the consistently ratio less than 0.1 , which indicates a reasonable level of consistency in the pairwise comparisons (Song, and Kang,2016), hence the decision process can continue.

Table 5: Weights of the criteria, sub-criteria

\begin{tabular}{|c|c|c|c|c|}
\hline Criteria & $\begin{array}{l}\text { Local } \\
\text { weights }\end{array}$ & Sub criteria & $\begin{array}{l}\text { Local } \\
\text { weights }\end{array}$ & $\begin{array}{l}\text { Global } \\
\text { weights }\end{array}$ \\
\hline \multirow[t]{4}{*}{ Financial } & \multirow[t]{4}{*}{0.412386} & Cash flow & 0.448326 & 0.184883 \\
\hline & & Return on investment & 0.209085 & 0.086224 \\
\hline & & Return on asset & 0.263555 & 0.108686 \\
\hline & & Logistics cost & 0.079034 & 0.032593 \\
\hline \multirow[t]{4}{*}{ Customer } & \multirow[t]{4}{*}{0.214385} & Customer satisfaction & 0.39295 & 0.084243 \\
\hline & & Sales volumes & 0.415677 & 0.089115 \\
\hline & & Customer retention & 0.093135 & 0.019967 \\
\hline & & On time delivery & 0.098237 & 0.021061 \\
\hline \multirow[t]{4}{*}{ Internal business } & \multirow[t]{4}{*}{0.299405} & New products and services & 0.073546 & 0.02202 \\
\hline & & $\begin{array}{l}\text { Availability } \\
\text { infrastructure }\end{array}$ & 0.513565 & 0.153764 \\
\hline & & Supplies cycle time & 0.196829 & 0.058932 \\
\hline & & Services process quality & 0.21606 & 0.064689 \\
\hline \multirow[t]{4}{*}{$\begin{array}{l}\text { Innovation } \\
\text { \&learning }\end{array}$} & \multirow[t]{4}{*}{0.073823} & Quality of documentation & 0.542 & 0.040012 \\
\hline & & Investment in training & 0.137 & 0.010114 \\
\hline & & $\begin{array}{l}\text { Logistics } \\
\text { system }\end{array}$ & 0.269 & 0.019858 \\
\hline & & $\begin{array}{ll}\text { Social } & \text { programs } \\
\text { investment } & \end{array}$ & 0.052 & 0.003839 \\
\hline
\end{tabular}

In interpreting these priorities, we see that manufacturer is the most preferable in terms of financial perspective (0.46596) and internal business (0.32047). Retailers is the most preferable in terms of customer (0.40968), the raw material is the most preferable in terms of Innovation $\&$ learning (0.38731). Wholesales is the least preferable in terms of financial (0.04886) and Innovation \& learning (0.0673). Accordingly, there is no alternative, which is the best alternative in terms of all the criteria. 
118 | International Journal of Scientific and Management Research 5(2) 109-123

4.1.1. Alternatives with respect to financial

\begin{tabular}{|l|l|l|l|l|l|l|l|}
\hline & $\begin{array}{l}\text { Raw material } \\
\text { supply }\end{array}$ & $\begin{array}{l}\text { Manufactu } \\
\text { rer }\end{array}$ & $\begin{array}{l}\text { Distribut } \\
\text { ors }\end{array}$ & $\begin{array}{l}\text { Wholesal } \\
\text { ers }\end{array}$ & $\begin{array}{l}\text { Retaile } \\
\text { ss }\end{array}$ & $\begin{array}{l}\text { Weigh } \\
\text { ts }\end{array}$ & $\begin{array}{l}\text { CR } \\
\text { Raw material } \\
\text { supply }\end{array}$ \\
\hline Manufacturer & 3 & $1 / 3$ & 3 & 4 & 5 & 0.2683 \\
6 & $\begin{array}{l}0.04 \\
9\end{array}$ \\
\hline Distributors & $1 / 3$ & 1 & 4 & 4 & 6 & 0.4659 \\
& & $1 / 4$ & 1 & 2 & 4 & 0.1342 \\
& & & & & & 5 \\
\hline Wholesalers & $1 / 4$ & $1 / 4$ & $1 / 2$ & 1 & 2 & 0.0825 \\
7
\end{tabular}

\subsubsection{Alternatives with respect to customer}

\begin{tabular}{|c|c|c|c|c|c|c|c|}
\hline & $\begin{array}{l}\text { Raw material } \\
\text { supply }\end{array}$ & $\begin{array}{l}\text { Manufactu } \\
\text { rer }\end{array}$ & $\begin{array}{l}\text { Distribut } \\
\text { ors }\end{array}$ & $\begin{array}{l}\text { Wholesal } \\
\text { ers }\end{array}$ & $\begin{array}{l}\text { Retaile } \\
\text { rs }\end{array}$ & $\begin{array}{l}\text { Weigh } \\
\text { ts }\end{array}$ & CR \\
\hline $\begin{array}{ll}\text { Raw material } \\
\text { supply }\end{array}$ & 1 & $1 / 4$ & $1 / 2$ & $1 / 4$ & $1 / 5$ & $\begin{array}{l}0.0612 \\
7\end{array}$ & \multirow[t]{5}{*}{$\begin{array}{l}0.08 \\
5\end{array}$} \\
\hline Manufacturer & 4 & 1 & $1 / 2$ & $1 / 3$ & $1 / 4$ & $\begin{array}{l}0.1187 \\
7\end{array}$ & \\
\hline Distributors & 2 & 2 & 1 & 2 & $1 / 2$ & 0.2171 & \\
\hline Wholesalers & 4 & 3 & $1 / 2$ & 1 & $1 / 3$ & $\begin{array}{l}0.1931 \\
8\end{array}$ & \\
\hline Retailers & 5 & 4 & 2 & 3 & 1 & $\begin{array}{l}0.4096 \\
8\end{array}$ & \\
\hline
\end{tabular}

\subsubsection{Alternatives with respect to internal business}

\begin{tabular}{|c|c|c|c|c|c|c|c|}
\hline & $\begin{array}{c}\text { Raw material } \\
\text { supply }\end{array}$ & $\begin{array}{c}\text { Manufactu } \\
\text { rer }\end{array}$ & $\begin{array}{c}\text { Distribut } \\
\text { ors }\end{array}$ & $\begin{array}{c}\text { Wholesal } \\
\text { ers }\end{array}$ & $\begin{array}{c}\text { Retaile } \\
\text { rs }\end{array}$ & $\begin{array}{c}\text { Weigh } \\
\text { ts }\end{array}$ & $\begin{array}{c}\text { CR } \\
\text { supply }\end{array}$ \\
\hline $\begin{array}{c}\text { Raw material } \\
\text { Manufacturer }\end{array}$ & 1 & $1 / 2$ & $1 / 3$ & 3 & 4 & 0.1932 & $\begin{array}{c}0.047 \\
9\end{array}$ \\
\hline Distributors & 2 & 1 & 1 & 4 & 4 & 0.3204 \\
7
\end{tabular}




\subsubsection{Alternatives with respect to innovation and learning}

\begin{tabular}{|c|c|c|c|c|c|c|c|}
\hline & $\begin{array}{ll}\text { Raw } & \text { material } \\
\text { supply } & \end{array}$ & $\begin{array}{l}\text { Manufactu } \\
\text { rer }\end{array}$ & $\begin{array}{l}\text { Distribut } \\
\text { ors }\end{array}$ & $\begin{array}{l}\text { Wholesal } \\
\text { ers }\end{array}$ & $\begin{array}{l}\text { Retaile } \\
\text { rs }\end{array}$ & $\begin{array}{l}\text { Weigh } \\
\text { ts }\end{array}$ & $\mathbf{C R}$ \\
\hline $\begin{array}{l}\text { Raw material } \\
\text { supply }\end{array}$ & 1 & 3 & 3 & 4 & 2 & $\begin{array}{l}0.3873 \\
1\end{array}$ & \multirow[t]{5}{*}{$\begin{array}{l}0.057 \\
4\end{array}$} \\
\hline Manufacturer & $1 / 3$ & 1 & $1 / 2$ & 3 & $1 / 4$ & $\begin{array}{l}0.1134 \\
2\end{array}$ & \\
\hline Distributors & $1 / 3$ & 2 & 1 & 2 & 1 & $\begin{array}{l}0.1754 \\
7\end{array}$ & \\
\hline Wholesalers & $1 / 4$ & $1 / 3$ & $1 / 2$ & 1 & $1 / 4$ & 0.0673 & \\
\hline Retailers & $1 / 2$ & 4 & 1 & 4 & 1 & 0.2565 & \\
\hline
\end{tabular}

\subsection{Final weight}

The matrix that summarizes the priorities for each step of the management cycle (alternative) in terms of each criterion is given below.

Table 6: Priority matrix

\begin{tabular}{|l|l|l|l|l|}
\hline & $\begin{array}{l}\text { Financial } \\
\mathbf{( 0 . 4 1 2 3 8 6})\end{array}$ & $\begin{array}{l}\text { Customer } \\
\mathbf{( 0 . 2 1 4 3 8 5})\end{array}$ & $\begin{array}{l}\text { Internal business } \\
\mathbf{( 0 . 2 9 9 4 0 5 )}\end{array}$ & $\begin{array}{l}\text { Innovation \& } \\
\text { learning (0.073823) }\end{array}$ \\
\hline Raw material supply & 0.26836 & 0.06127 & 0.19323 & 0.38731 \\
Manufacturer & 0.46596 & 0.11877 & 0.32047 & 0.11342 \\
Distributors & 0.13425 & 0.2171 & 0.32698 & 0.17547 \\
Wholesales & 0.08257 & 0.19318 & 0.09206 & 0.0673 \\
Retailers & 0.04886 & 0.40968 & 0.06725 & 0.2565 \\
\hline
\end{tabular}

The overall priority for each decision alternative is obtained by summing the product of the criterion priority times the priority of the decision alternative with respect to that criterion. The criterion priorities were 0.4123 for financial perspective, 0.2144 for customer perspective, 0.2994 for internal business perspective, and 0.0738 for and innovation $\&$ learning perspective. Thus, the computation of the overall priority for raw material is as follows overall raw material priority $0.26836(0.412386)+0.06127(0.214385)+0.19323(0.299405)+0.38731(0.073823)$. Repeating this calculation for other alternatives.

The results of relative priorities for the five alternatives with respect to the overall goal show that the most important stage is the manufacturer (with a priority of 0.3235 ). Distributors (with a priority of 0.2123 ) is second, followed by raw material (with a priority of 0.2109 ), retailers (with a priority of 0.1457 ), and wholesales (with a priority of 0.1077 ). 
Table 7: Results of model selection AHP-BSC

\begin{tabular}{|l|l|l|l|l|l|}
\hline Graphic & Alternatives & Total & Normal & Ideal & Ranking \\
\hline \multirow{5}{*}{} & Raw material & 0.1054 & 0.2109 & 0.652 & 3 \\
\cline { 2 - 7 } & Manufacturer & 0.1617 & 0.3235 & 1 & 1 \\
\cline { 2 - 7 } & Distributors & 0.1061 & 0.2123 & 0.6562 & 2 \\
\cline { 2 - 7 } & Wholesales & 0.0538 & 0.1077 & 0.3328 & 5 \\
\cline { 2 - 6 } & Retailers & 0.0729 & 0.1457 & 0.4505 & 4 \\
\hline
\end{tabular}

\subsection{The sensitivity analysis}

The sensitivity analysis helps to understand the impact of changing various priorities criteria values on alternatives' priorities. It also performs to test priority ranking stability (Chang et al., 2007). This sensitivity analysis consists of identifying the variables that most affect the choice of alternatives. Determine the most sensitive variables, the variables for which a variation in value causes changes in the alternatives' ranking results.

The figure. 3 shows the sensitivity graph of AHP results. The weight of the criteria are on the $\mathrm{x}$-axis, and alternatives are on the $\mathrm{y}$-axis. The manufacturer is the best alternative among the five alternatives and financial the most influential criteria. The alternative "manufacturer" was mainly prioritized by the criteria "financial and international business". However, the customer perspective presents a great influence on the retailer stage, and the internal business perspective presents a great influence on the manufacturer and distributors stage. Wholesales, on his side, appear to have a moderate performance on all criteria. 


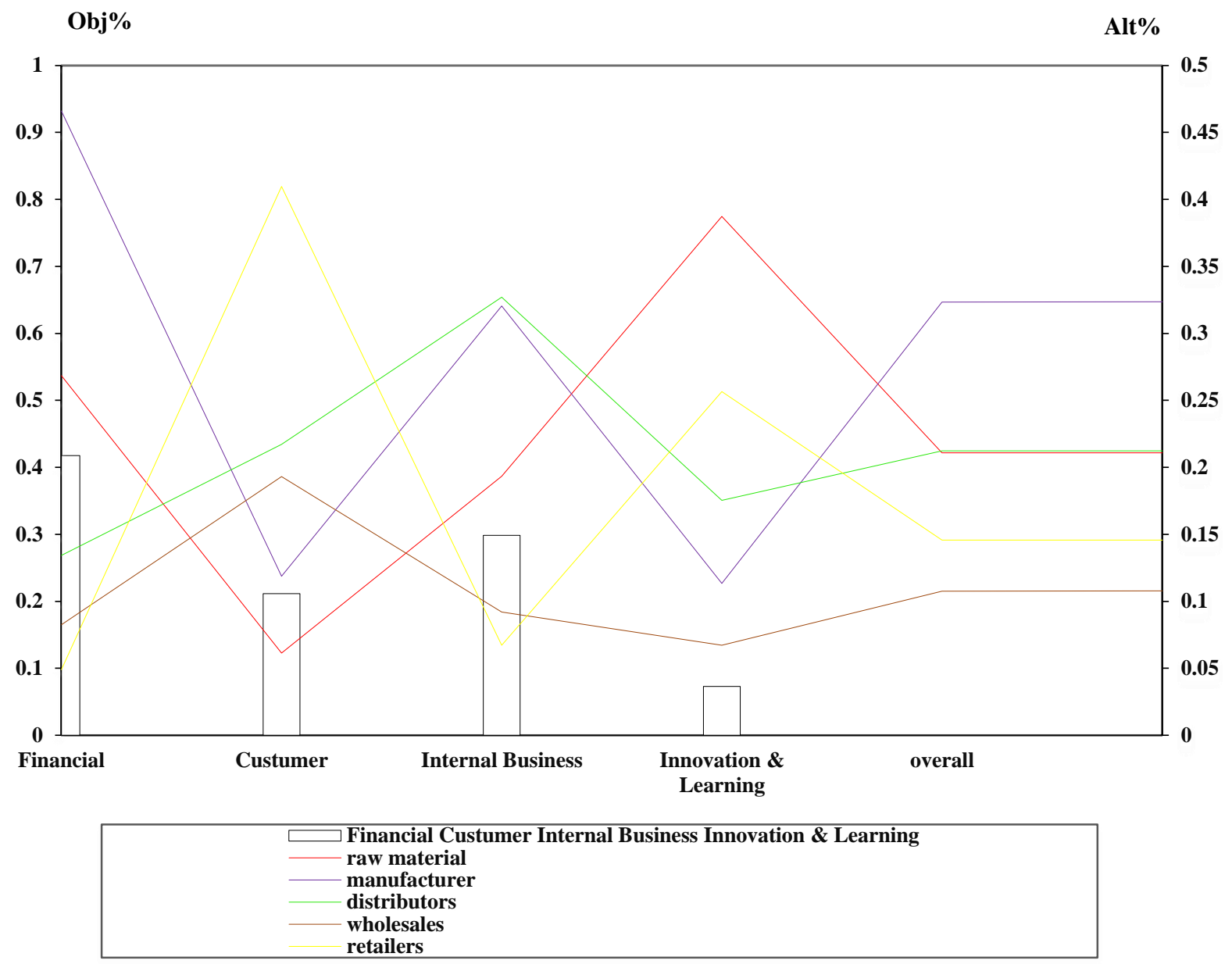

Fig 3: Performance sensitivity of alternative

\section{Conclusion}

The presented methodology indicates how the logistics management process could be developed and improved to meet customer requirements. Logistics management process flows outline and traces the process flow of transportation at the different distribution channel stages. The purpose of this study was to use the integrated BSC-AHP in the evaluation of the logistics management process to help managers prioritizing and selecting performance measures best suited to fulfill the goals. One of the greatest challenges in general task management and logistics is to assign a high priority to each of the objectives set to optimize time and increase efficiency. Indeed, logistics would like to focus first on what seems to be most urgent. From this perspective and despite all the constraints it implies, i.e. time, finances, there is not enough time to differentiate between the most urgent and the most important. Further research will be directed towards analysis and applying other analytical tools in the model developed, and then provide an additional perspective on the issue developed. 


\section{References}

1) Ballou, R. H. (2007). The evolution and future of logistics and supply chain management. European business review.

2) Chang, C. W., Wu, C. R., Lin, C. T., \& Chen, H. C. (2007). An application of AHP and sensitivity analysis for selecting the best slicing machine. Computers \& Industrial Engineering, 52(2), 296-307.

3) Chin, K. S., Chan, B. L., \& Lam, P. K. (2008). Identifying and prioritizing critical success factors for coopetition strategy. Industrial Management \& Data Systems.

4) Christopher, M. (1993). Logistics and competitive strategy. European Management Journal, 11(2), 258-261.

5) Cooper, M. C., Lambert, D. M., \& Pagh, J. D. (1997). Supply chain management: more than a new name for logistics. The international journal of logistics management, $8(1)$, $1-14$.

6) Cousins, P. D., Lawson, B., \& Squire, B. (2006). Supply chain management: theory and practice-the emergence of an academic discipline?. International Journal of Operations \& Production Management.

7) Daugherty, P. J., Ellinger, A. E., \& Gustin, C. M. (1996). Integrated logistics: achieving logistics performance improvements. Supply Chain Management: an international journal.

8) Dobrovic, Z., \& Penic, S. (2008). Managing Private Higher Learning Institutions with the Support of Information Technology: Strategic Framework. In Central European Conference on Information and Intelligent Systems (p. 1). Faculty of Organization and Informatics Varazdin.

9) Germain, C., \& Trebucq, S. (2004). La performance globale de l'entreprise et son pilotage: quelques réflexions. Semaine sociale Lamy, 1186, 35-41.

10) Gunasekaran, A., \& Kobu, B. (2007). Performance measures and metrics in logistics and supply chain management: a review of recent literature (1995-2004) for research and applications. International journal of production research, 45(12), 2819-2840.

11) Hausman, A., Johnston, W. J., Gundlach, G. T., Bolumole, Y. A., Eltantawy, R. A., \& Frankel, R. (2006). The changing landscape of supply chain management, marketing channels of distribution, logistics and purchasing. Journal of business \& industrial marketing.

12) Kaplan, R. S., \& Norton, D. P. (1998). Putting the balanced scorecard to work. The economic impact of knowledge, 27(4), 315-324.

13) Kohneh, A. V. M. A., Yazdani, B., \& Kamalian, A. (2013). Performance measurement in governmental agencies using BSC-AHP: A case study of Civil Registry Office in Tehran. Management science letters, 3(4), 1255-1260.

14) Lambert, D. M., \& Stock, J. R. (1993). Strategic logistics management (Vol. 3, pp. 306318). Homewood, IL: Irwin.

15) Lummus, R. R., Krumwiede, D. W., \& Vokurka, R. J. (2001). The relationship of logistics to supply chain management: developing a common industry definition. Industrial management $\&$ data systems. 
16) Moberg, C. R., Whipple, T. W., Cutler, B. D., \& Speh, T. W. (2004). Do the management components of supply chain management affect logistics performance? The International Journal of Logistics Management.

17) Murthy, M. R. K. (2015). Performance Assessment of Agricultural Research Organisation Priority Setting by using Balanced Score Card (BSC) \& Analytic Hierarchy Process (AHP) technique. Journal of Business and Management, 17.12: 6274

18) Pettit, S. J., \& Beresford, A. K. (2005). Emergency relief logistics: an evaluation of military, non-military and composite response models. International Journal of Logistics: Research and Applications, 8(4), 313-331.

19) Ramasamy, N., Rajesh, R., Pugazhendhi, S., \& Ganesh, K. (2016). Development of a hybrid BSC-AHP model for institutions in higher education. International journal of enterprise network management, 7(1), 13-26.

20) Rezaee, Z. (2018). Supply chain management and business sustainability synergy: A theoretical and integrated perspective. Sustainability, 10(1), 275.

21) Saaty, T. L. (1980). The analytical hierarchy process, planning, priority. Resource allocation. RWS publications, USA.

22) Saaty, T. L., \& Vargas, L. G. (1991). Prediction, projection, and forecasting: applications of the analytic hierarchy process in economics, finance, politics, games, and sports. Kluwer Academic Pub.

23) Sharma, M. K., \& Bhagwat, R. (2007). An integrated BSC-AHP approach for supply chain management evaluation. Measuring Business Excellence.

24) Song, B., \& Kang, S. (2016). A method of assigning weights using a ranking and nonhierarchy comparison. Advances in Decision Sciences, 2016.

25) Southern, R. N. (2011). Historical perspective of the logistics and supply chain management discipline. Transportation Journal, 50(1), 53-64. 